\title{
Agroforestry Land Management with the Community of Candi Rejo Village, Biru-Biru District, Deli Serdang, North Sumatra
}

\author{
Delvian $^{1}$, Deni Elfiati ${ }^{1}$, Ridahati Rambey ${ }^{1 *}$ \\ ${ }^{1}$ Forestry Department Faculty of Forestry, Universitas Sumatera Utara \\ *Email: ridahati.2017@gmail.com
}

\begin{abstract}
Community Service Program in agroforestry land management together with the people of Candi Rejo of Village, Biru- Biru Sub-District, Deli Serdang, North Sumatra, aims to assist the community in managing agroforestry land to improve community skills in managing their agroforestry land. Some of the activities carried out are making compost using cocoa waste and animal husbandry, prunning cocoa plants to reduce pest and disease attacks and planting mindi, avocado, durian species for enrichment of species on agroforestry land. Based on the result of interviews with farmers that the use of compost is more effective in increasing cocoa production.
\end{abstract}

Keyword: Agroforestry, land management, community

\section{INTRODUCTION}

Agroforestry is an agricultural pattern used in this village, where combination of species such as durian (Durio Zibethinus), Mindi (Melia azedarach), coconut (Cocos nucifera) with cocoa (Theobrema cacao) are the choices used by the community. Agroforestry land management is important in sustainable land management. The agroforestry pattern is a pattern that rarely fails because the product are various types. The community has long applied agroforestry pattern, but land management has not been given much attention so that the benefit that are utilized are not optimal. Land management in question is fertilizing, tillage and combining plant species.

The choice of plants species to be one of the choice is one of the important factors in success in agroforestry. Agroforestry in question in management of land that combines agricultural crops, forestry in one land with the regulation of spice and time. The combination of wood types and agricultural crops must be considered suitability. Cocoa pod husk in one of the wastes from cocoa plantations. If not utilized it can be an environmental problem in around plantation. One of the ways to utilize cocoa pod husk is to make compost which can be used as organic fertilizer. Cocoa pod husk can cause environmental pollution because the cocoa pod husk requires relatively long time if it decomposes naturally without a activator. Cocoa pod husk also has the potential to become a place to grow various diseass, especially on cocoa plants (Priyanto et al, 2004 )

This type of cocoa is a plantation commudity that is harvested every week and produces cocoa waste that has the potential to be composted therefor, the socialization and practice of agroforestry land management is very much needed to support the management of farmers' land. Service activities that will be carried out are enrichment of multipurpose tree species and composting training in farmer group in Candi Rejo Vallage. Composting training is an important thing to do to meet the fertilizer needs of farmer. Higher education cooperation as community partners in solving this problem is needed by farmers. This is also in accordance with the Tri Dharma of Higher Education, where Universities are required to do community service in order to participate in helping the problem that text exist in the community. 


\section{MATERIAL AND METHODS}

\subsection{Socialization of agroforestry garden management.}

The practice of arranging garden space. Related to the proper planting distance in a garden, pruning, organic fertilizing and combining plant species. The method of activities carried out in this study is to conduct a Focus Group Discussion about each farmers' land, then field practice.

\subsection{Making cocoa compost}

- Training on the use of species and technology in composting techniques from organic materials using EM4 to target communities.

- Implementations of activities by applying science and technology at the target location to improve skill and skills in the composting process.

- Introduction of microbial types and their benefit during the composting process- Monitoring and enhancing community participation to participate in training and composting science and technology activities.

\subsection{Planting of Multiporpuse tree species (MPTS ) on land boundaries or cocoa growing trees.}

The type of MPTS in question is the type that can be utilized by both wood and fruits. Types include durian, avocado, mindi and others. The selected wood species sush as mindi wood are used as cocoa shade trees. In addition to mindi wood can also be used as raw material in the manufacture of vegetable pesticides.

\section{RESULT AND DISCUSSION}

\section{a. Compost Making}

Composting is carried out on July 9, 2019. The materials used include cacao skin waste originating from farmers' farms, animal dung (goats), banana stems, EM4, local microorganisims (MOL). The amount of compost produced reaches on ton. Cocoa shells that have been peeled are usually collected by farmers and put into sacks as compost- making material that is routinely done. Based on interviews with cocoa fertilizers using compost is more effective than chemical fertilizer.

According to Saragih (2017) cocoa pod compost has a significant effect on increasing plant height, leaf area, and stem circumference. The composting process is done first by preparing the material and tools needed. The location of composting is in the garden using tarp as a base and compost cover. The compost material collected is mixed evenly and watered with EM4 to help the compost decomposition process. If EM4 is not available, people usually make local microorganisims (MOL). Once a week the compost is checked if it is less moist then EM4 is flushed again so that the decomposition process is faster. Usually, if the manufactureing process is good, compost can be used after 1 month.

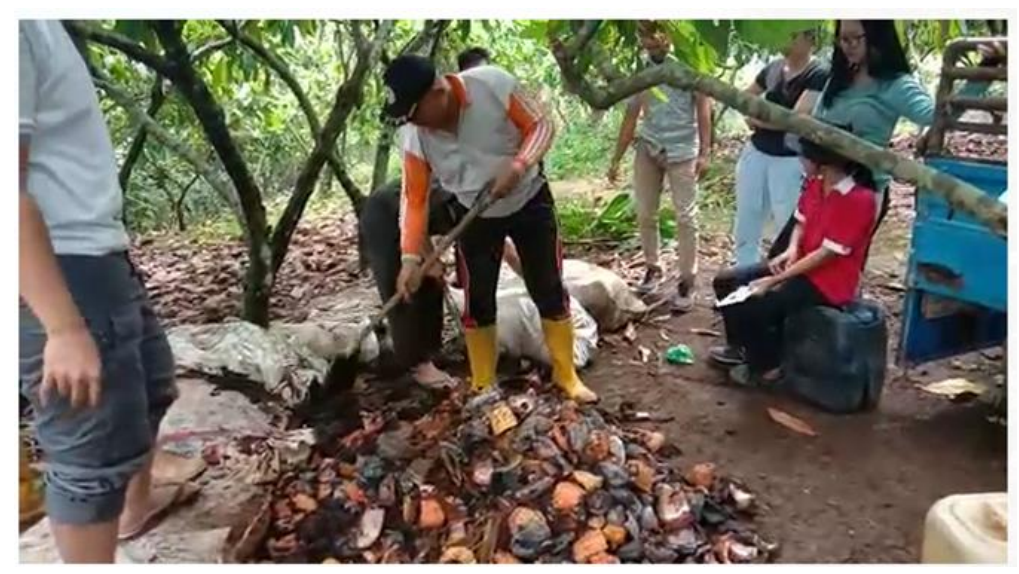

Figure1. Making Cocoa Compost 
According to an interview with the chairman of the farmers' group, Hartono said that "the use compost to increase plant growth on cocoa trees is better than the use of chemical fertilizer. According to Didik and Yufnal (2004) states that cocoa pod compost has a $\mathrm{pH}$ of 5.4, a total $\mathrm{N}$ of $1.30 \%, \mathrm{C}$ organic $33,71 \%, \mathrm{P} 2 \mathrm{O} 50,186 \%, \mathrm{~K} 2 \mathrm{O} 5,5 \%, \mathrm{CaO} 0,23 \%$ and $\mathrm{MgO} 0,59 \%$ can therefore improve the physical, chemical and biological poor soil properties. According to the result of Baihaqi's research (2015) that cocoa yield showed an increase in treatment by giving $9 \mathrm{~kg}$ of compost/ tree. Provision of 15 tons/ ha of organic fertilizer produces the best cocoa field.

\section{b. Pruning Tress}

Cacao pruning has the objective: (1) to obtain a good basic branching framework for cocoa plants, (2) to regulate the distribution of branches and productive leaves in the canoply evenly, (3) to remove unwanted plant parts, such as water shoots and diseased branches, broken, hanging, and inverted branches, (4) Spur plants to from few leaves that are potential sources of assimilation, (5) reduce the risk of pests and disease, and (6) increase fruit-bearing plants. In addition to pruning cocoa plants, pruning of protective trees needs to be done so that the braches and leaves grow tall and good. Trees that are left without pruning will limit the growth of cocoa, because it blocksthe sun's rays and creates competition with major crops for water and nutrients (Bali Agricultural Research and Development, 2014 ).

Prunning by farmer in Candi Rejo Village is usually six months. Cocoa pruning is one of the activities of cocoa plantation management to increase cocoa production. Pandawa farmer group is a farmer group that concentrates on cocoa plants. Regular group meeting are held once a month to increase knowlagde in the field of cocoa planting. Usually, the meeting place is in the farmer,s garden which is carried out in turns. The aim is that the group members gardens can be monitored jointly by group.

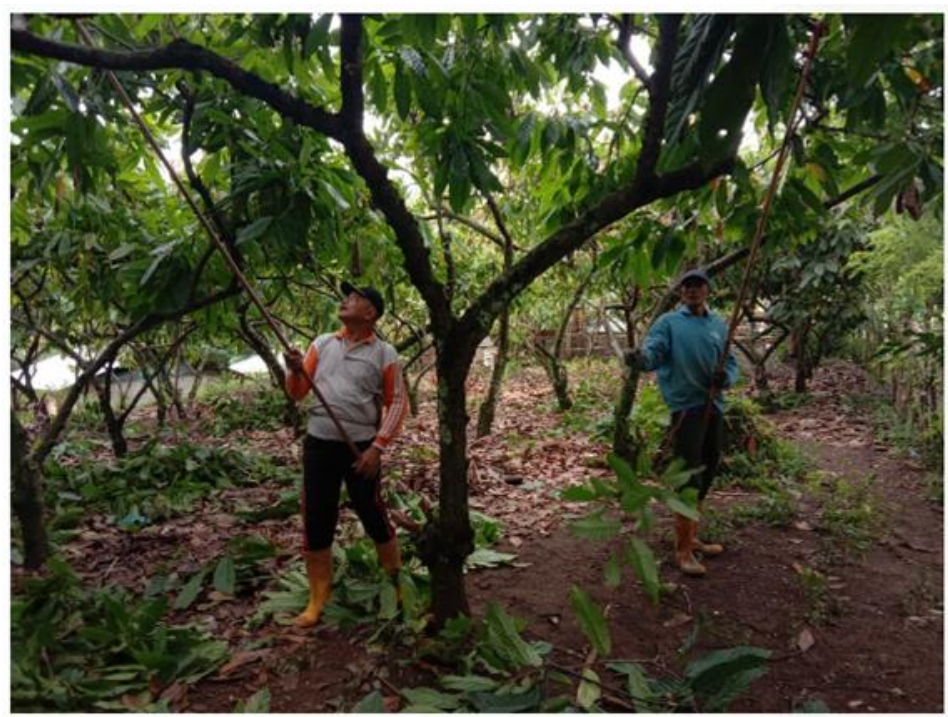

Figure 2. Cocoa pruning activities

According to the result of Baihaqi research (2015) that the dry weight of cocoa beans tends to be greater in the treatment by pruning. The combination of composting $13,5 \mathrm{~kg} /$ plant with pruning showed the hightes average of the total variables and dry weight of cocoa beans.

\section{c. Agroforestry Land Enrichment}

Enrichment of tress species is done by adding species or increasing the number of protective tress such as durian (Durio Zibethimus), Avocado (Persia Americana) and mindi (Melia azedarach). These three types of tress are usually used by the community such as cocoa protectors. Beside from being a protector of cocoa trees it also pruduces economically with fruit and wood 
production. Enrichment of tree species can be planted on vacant land in the garden or the edge of the garden boundary. Good garden management is the key to success in agroforestry land management.

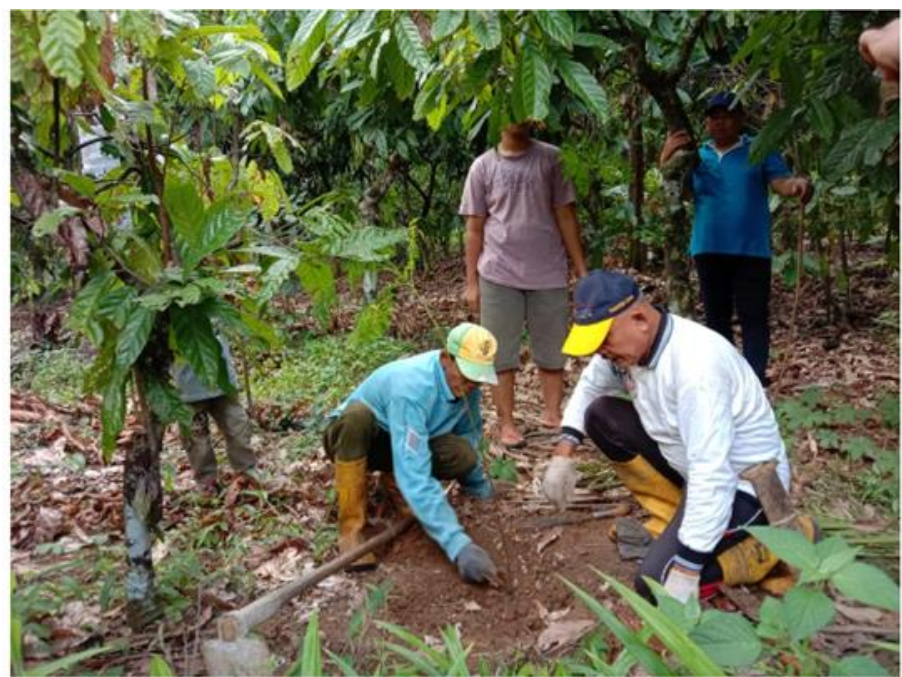

Figure 3. Mindi tree ( Melia azedarach ) planting activity

Hiola Research results (2017), Ilengi agroforestry that planted tree species with the aim of fruiting, planting of plant is done with a rather wide distance with the intention of the tree can grow optimally, on the contrary on agroforestry ilengi with the aim of wood, the tree is allowed to grow with a tight spacing without any thinning efoert because farmer think they will lose if thinning is done.

\section{CONCLUSION}

The majority of residents of Candi Rejo Village are cocoa farmer and ranchers. Agroforestry land management practices are urgently needed to support farmers land management. Community service activities include enriching multipurpose tree species and composting graining for farmer groups in Candi Rejo village. Compost making trainingis an important thing to do to meet the fertilizer needs of farmers. Higher educations cooperation as community partners in solving this problem is needed by farmers.

\section{ACKNOWLEDGMENTS}

We would like to express our gratitude to Universitas Sumatera Utara for funding this activity through Program Pengabdian Kepada Masyarakat of Year 2019

\section{REFERENCES}

Baihaqi A, HAmid AH, Anhar A, Abubakar Y, Anwar T, Zazunar Y. 2015. Aplication of Cultivation Techniques and the relationship Beteen Prunning and Increasing Soil Fertility Againts Increased Cocoa Productivity in Pidie Regency. Agrisep Vol (16) No.2, 2015.

Damanik, HF, et al. 2013. Response of Growth of Cocoa Seedlings (Theobrema cocoa L) on some Compost Composition of Cocoa Fruit Skin with Ultisol Subsoil and Leaf Fertilizer. Agroecotechnology Online Journal. Vol. 2. No. 1:162-171. Desember 2013. 
Didik H.G and Yufnal Away. 2004. Orgadek, Composting Activator. Development of Research Result in the Bogor Plantation Biotechnology Research Unit

Hiola AS. 2017. Study of tree species Selection in llengi agroforestry Based on Bioohysical, Landscape and Sosio Economic Factors with Local Usedr Value Index (LUVI) Approach. Journal. Unismuh.ac.id matoa, article.

Isroi 2007. Composting of Cocoa Waste. http://isroi.wordpress.com. Accessed on April 14, 2016 Anonymous, 2011. Cocoa bark, high Selling Value Waste.https://laskarpemberani.files.wordpress. com. Accessed on April 14, 2016.

Rosniawaty, S. Effect of Cocoa Fruit Skin Compost and Kascing Against Cocoa (Theobrema L Cocoa) Growth of Upper Amazona Hybrid Cultivars. Department of Acriculture Cultivation, Faculty of Agriculture, UNPAD .

Saragih DP, Ardian. 2017. The Effect of Cocoa Fruit Skin Compost on Growth of P (Theobroma cacao L. )Hybrid Cocoa Seeds. JOM FAPERTA Vol.4 No.2 OCTOBER 2017.

Surtinah 2013. Testing the Nutrient Content in Compost Sprouting from Litter Sweet Corn (Zeamays saccharat ). Agricultural Scientific Journal Vol.11, No. August 1, 2013.

The Central of Statistics. 2016 b. Regional Statistics District Biru-biru. Central Bureau of Statistics Deli Serdang Regency. Deli Serdang.

The Institution Central of Statistics. 2016a. Deli Serdang in Numbers: 2015. The central Statistic Agency for Deli Serdang Regency. 